\title{
PELATIHAN PLATFORM ARDUINO UNTUK FUNGSI SWITCHING, MONITORING, DAN PENGONTROL BAGI SMK DI WILAYAH BEKASI
}

\section{ARDUINO PLATFORM TRAINING FOR SWITCHING, MONITORING, AND CONTROL FUNCTIONS IN SMK BEKASI REGION}

\author{
Mauludi Manfaluhty dan Sinka Wilyanti \\ Teknik Elektro Sekolah Tinggi Teknologi Jakarta \\ Email: mauludi@gmail.com
}

\begin{abstract}
ABSTRAK
Ada dua hal yang harus dikuasai untuk bisa menjadi perekayasa sistem pintar (smart system), yaitu keahlian menggunakan hardware, software dan brainware. Guna menunjang kebutuhan keahlian tersebut, maka diperlukannya pencerahan dan penjelajahan di dunia mikrokontroler yang tidak hanya digunakan untuk membuat robot mainan dan sarana lomba (kontes) tetapi memang mampu berperan di kehidupan nyata. Dalam rangka menyederhanakan penggunaan mikrokontroler yang terlihat canggih, rumit, dan bentuk mainan yang direpresentasikan dalam robot, menjadi bentuk yang lebih friendly dalam kehidupan sehari-hari, misalnya home automation, kendali otomatis, rumah pintar, sepeda pintar, dan lain-lain. Pada pelatihan ini siswa-siswi membuat beberapa proyek dengan mengikuti petunjuk dari modul-modul pelatihan, misalnya kontrol lampu, display, monitoring jarak, PWM, dan lain-lain. Pendekatan ini memiliki keuntungan tersendiri karena siswa-siswi sudah dapat membayangkan apa yang akan mereka laksanakan dibandingkan jika mereka belajar melalui media visual maupun audio. Dengan mempelajari berbagai cara kerja sensor input dan output, pada siswa-siswi diberikan komponen-komponen pendukung lainnya berupat kit yang siap digunakan dalam berbagai proyek. Pendekatan ini juga diharapkan dapat meningkatkan kreativitas siswa-siswi, karena mereka dirangsang untuk membuat proyek dari komponen-komponen yang tersedia/dipelajari.
\end{abstract}

Kata Kunci: Arduino, sistim benam, mikrokontroler, Arduino Uno, Papan Latih Arduino

\begin{abstract}
There is two things that must be mastered to be a smart system, which is the expertise of using hardware, software and brain ware. In order to support the needs of these skills, the need for enlightenment and exploration in the microcontroller world that is not only used to make robot toys and contest facilities but is able to play a role in real life. In order to simplify the use of microcontrollers that look sophisticated, elaborate, and the form of toys that are represented in robots, to become more friendly in everyday life, such as home automation, automatic control, smart homes, smart bikes, and so on. In this training the students make several projects in following the instruction of the training modules, such as display light control, distance monitoring, PWM, and others. This approach has its own advantages because students can already imagine what they will do than if they learn through visual or starter kit media. By studying the various ways in which the input and output sensor work, students are provided with other support components that are ready for use in various projects. This approach is also expected to increase the creativity of students, as they are stimulated to make projects of the components available.
\end{abstract}

Keywords: Arduino, Arduino Trainer, Arduino Uno, Microcontroller, System Embedded. 


\section{PENDAHULUAN}

Di era tahun 1990, kemahiran menuliskan kode program merupakan suatu keterampilan langka. Hal ini didukung juga oleh fungsi program yang pada waktu itu berfokus sebagai pertukaran informasi dan bagian dari proses administrasi. Pengaruh itu sampai sekarang masih terasa, hal ini bisa kita rasakan ketika mengembangkan sistem informasi. Kita bicara Sistem Informasi, bukan Program Informasi, pada kenyataannya masih banyak orang awam, atau bahkan user dan calon user yang mempunyai pengertian bahwa maksud dari sistem informasi tetap saja program, jadi pada dasarnya yang namanya sistem informasi terkait dengan Sumber Daya Manusia, Proses, dan Teknologi. Dahulu yang namanya sistem informasi berfokus pada manajemen informasi yaitu bagaimana menangkap, menghasilkan, mengolah, dan mendistribusikan (mengirimkan) ke pihak-pihak yang berkepentingan. Jadi fokus utamanya pada waktu itu adalah Otomatisasi. Misalnya, jika dahulu daftar sekolah harus menggunakan formulir kertas, saat ini sudah bisa langsung diisi di komputer, dokter jika akan mencari rekam medis (medical record) harus bongkar laci dan memilih satu persatu nomor pasien yang pernah daftar, saat ini hanya tinggal ketikkan saja di tempat pencarian, search dan tampillah data yang diinginkan (kalau memang datanya ada).

Perkembangan selanjutnya menuntut bahwa informasi tidak cukup hanya diambil (diciptakan), diproses, dan distribusikan, namun harus juga mampu memberikan nilai pengetahuan dan bahkan mengambil tindakan sesuai informasi yang diterima. Artinya pengguna tidak lagi hanya bisa membaca informasi, kemudian terserah penggunalah informasinya mau diapakan, tetapi sistem juga harus mampu mengambil tindakan seperti pengguna mengambil tindakan. Maksudnya, yang tadinya dikerjakan manusia, sekarang sudah bisa dikerjakan oleh sistem itu sendiri. Contoh: di masa lampau informasi penjual hanya bisa menampilkan angka-angka dan diputuskan oleh para manajer pemasaran, tetapi sekarang sistem penjualan sudah mampu memutuskan tindakan penjualan yang harus dilakukan para petugas di lapangan berdasarkan informasi yang ada. Contoh lainnya, mesin las di pabrik mobil sudah bisa melakukan pengelasan sampai satuan milimeter berdasarkan informasi bahan yang dimasukkan pada sistemnya. Jadi, sistem informasi sekarang tidak hanya menghasilkan dan menyajikan informasi tetapi juga sudah memiliki pengetahuan dan kemampuan mengambil tindakan/keputusan berdasarkan informasi yang diterima oleh sistem tersebut. Hal ini dilakukan dengan teknik yang disebut Kecerdarsan Buatan (Artificial Intelligence). Dengan menggunakan teknologi ini, sistem atau mesin seolah-olah memiliki kecerdasan seperti manusia. Dengan adanya kebutuhan dan tuntutan kebutuhan dikehidupan manusia yang memerlukan kecepatan, ketepatan dan ketersediaan yang serba cepat/instant, sistem informasi tidak lagi hanya berurusan dengan data atau informasi, tetapi juga harus mampu berinteraksi dengan lingkungan. Harus mampu menangani dan berinteraksi dengan perangkat keras atau keadaan di sekitar. Misalnya dalam teknologi Air Conditioner (AC), kecepatan motornya bisa dipercepat atau diperlambat dengan tidak dikendalikan melalui remote control, tetapi membaca sensor-sensor suhu/monitoring, dan gerakan yang terjadi di ruangan. Dengan ini manusia tidak lagi harus mengatur ulang/mengotnrol suhu AC karena perangkat AC tersebut sudah mampu mengatur suhunya sendiri berdasarkan jumlah orang dalam suatu ruangan dimana AC tersebut ditempatkan. Sistem-sistem yang mampu mengatur dirinya sendiri, melakukan tindakan memutuskan /switching 
dan hal-hal umum lainnya yang biasanya dilakukan manusia disebut dengan Sistem Pintar (Smart System).

Sistem-sistem pintar inilah yang ke depan akan mendominasi dalam aspek/kehidupan manusia, mempermudah dan meningkatkan taraf hidup. Karena itu, para programmer yang biasanya hanya berkutat pada database dan aliran informasi, sudah saatnya menambah kemampuan dan keterampilan dalam menangani perangkatperangkat keras, termasuk sensor-sensor, mesin-mesin dan peralatan mekanis lainnya. Program-program yang selama ini sebenarnya hanya memproses dan mengalirkan informasi, harus mampu mewujudkan informasi tersebut dalam bentuk sesuatu, misalnya tindakan atau aksi. Di sinilah konversi virtual ke dunia nyata terjadi (virtual to real world). Untuk menjembatani atau menghubungkan dunia virtual dan dunia nyata tersebut, fungsi teknik digital berada. Diwujudkan dalam suatu bentuk rangkaian mikrokontroler. Dengan mikrokontroler memungkinkan bahasa pemrograman dan logikanya (algoritma) yang bersifat virtual dapat dikonversikan menjadi aksi nyata pada peralatan elektonik ataupun mekanik. Inilah yang menyebabkan kenapa para programmer dan perekayasa sistem informasi tidak lagi hanya bisa menangani algoritma dan alur data /informasi, tetapi juga harus bisa merencanakan bagaimana data/informasi tersebut bisa dirubah dalam tindakan mekanis. Contoh yang sudah sangat populer di kalangan mahasiswa atau mungkin juga umum adalah robot. Banyak orang mempelajari teknik robotika untuk bisa membuat peralatan mekanis yang bisa meniru tingkah laku manusia atau membuat sebagai alat bantu meringankan pekerjaan. Bahkan dengan teknologi robot ini, mampu mengurangi risiko keselamatan jiwa manusia, misalnya robot penjinak bom, dan UAV (Unmanned Aerial Vehicle) yang memungkinkan manusia menjelajah dan melaksanakan aksi-aksi berbahaya dengan risiko nyawa dan keselamatan yang minimal.

Dalam meningkatkan pemahaman proses belajar mengajar serta mengantisipasi kebutuhan khusus/skill saat berada di dunia kerja, saat ini mitra/sekolah memiliki kekurangan, yaitu tidak adanya alat peraga/emulator yang dapat mendukung proses pemahaman siswa-siswi terhadap suatu bidang pelajaran terutama fisika, elektronika, mekatronika. Dengan Emulator Arduino ini diharapkan dapat merangsang daya nalar dan imajinasi siswa-siswi terutama dibidang ilmu elektronika, instrumentasi dan kontrol.literatur terdahulu (state of the art) untuk menunjukkan kebaruan ilmiah artikel tersebut.

SMKN 1 Kabupaten Bekasi ini selain memiliki kelebihan tentunya ada beberapa kekurangan dalam proses belajar mengajar, yaitu kekurangan alat peraga/emulator yang dapat mendukung proses pemahaman siswa terhadap suatu bidang pelajaran terutama fisika/elektronika. Emulator Arduino ini dibutuhkan untuk merangsang daya nalar dan imajinasi siswa terutama dibidang ilmu elektronika, instrumentasi dan kontrol. Dengan adalanya Emulator Arduino ini, maka dapat membantu proses belajar siswa dalam memahami sebuah ilmu fisika/elektronika. Saat ini, tidak ada emulator yang dimiliki oleh SMKN 1 Kabupaten Bekasi khususnya yang berkaitan dengan ilmu elekronika

Untuk mendukung proses belajar pada SMK Insan Mulia saat ini sudah ada dua laboratorium yaitu laboratorium software dan laboratorium hardware dengan beberapa keterbatasan yang ada. Laboratorium Hardware lebih fokus pada perakitan PC (personal computer) serta trouble shooting. Sedangkan laboratorium software lebih banyak memberikan pelajaran software aplikasi untuk mendukung jurusan Multimedia. Di 
karenakan keterbatasan dana, ada beberapa kekurangan dalam proses belajar mengajar di SMK Insam Mulia, yaitu kekurangan alat peraga/emulator yang dapat mendukung proses pemahaman siswa terhadap suatu bidang pelajaran terutama fisika/elektronika yang berkaitan dengan jurusan teknik komputer dan jaringan. Eimulator Arduino ini dibutuhkan untuk merangsang daya nalar dan imajinasi siswa terutama dibidang ilmu komputer dan jaringan. Dengan adalanya emulator Arduino ini, maka dapat membantu proses belajar siswa dalam memahami penggunaan arduino pada jaringan komputer.

Pada program pengabdian pada Masyarakat ini, target yang akan diberikan adalah pembuatan Emulator Arduino, pembuatan - Modul-modul projek Arduino, pembuatan panduan pelatihan dan pelatihan pada SMK.

Dari Pelatihan program pengabdian masyarakat dalam pelatihan luaran yang diharapkan adalah sebagai berikut :

1. Dengan tercapainya pelatihan arduniono ini bagi siswa-siswa SMK di Bekasi diharapkan para peserta dapat menciptakan laboratotium kecil di sekolahnya sekaligus modal untuk masuk ke dunia kerja dan kewirausahaan di bidang mikrokontroler.

2. Mendorong terciptanya lapangan kerja baru

3. Dari program ini diharapkan memberikan pengembangan ketrampilan mikrokontroler pada siswa-siswa adik kelas di SMK tersebut.

\section{METODE PELAKSANAAN}

Metode pelaksanaan Iptek Bagi Masyarakat (IBM) ini dilakukan dalam beberapa tahapan seperti:

\section{Studi Kepustakaan}

Faktor yang mempengaruhi hasil belajar siswa menurut Purwanto (1990:107), dikelompokkan menjadi dua faktor yaitu faktor internal dan faktor eksternal. untuk factor internal meliputi fisik, psikis seperti minat, kesehatan dan motivasi. Faktor eksternal meliputi guru, sarana, prasarana, kurikulum dan lain lain. kalau dilihat dari sarana dan prasarana pembelajaran, akan berhubungan erat dengan media pengajaran dan alat peraga. Menurut Arsyad (2002:3), media adalah segala bentuk dan saluran yang digunakan untuk menyampaikan pesan atau informasi. Menurut Sudjana (2000:110). Model Arduino yang akan digunakan dalam pelatihan ini berfungsi sebagai eimulator/alat peraga/ alat pembelajaran yang pada dasarnya adalah alat bantu yang digunakan oleh guru, siswa dalam proses belajar mengajar mikrokontroller agar proses belajar siswa lebih efektif dan efisien.

\section{Perakitan Modul Ardunio Hardware}

Setelah mendapatkan metode pembelajaran yang sesuai, tahapan selanjutnya adalah melakukan perakitan hardware. Perakitan ini bertujuan untuk memastikan bahwa konsep yang akan di aplikasikan sesuai dengan kebutuhan yang ada pada mitra. Disamping itu, perakitan ini untuk memberikan gambaran kepada pihak mitra bagaimana merakit arduino yang akan dibuat dan spesifikasi komponen pendukungnya.

\section{Installasi Arduino Software}

Pada proses ini, software dari arduino akan di install pada laptop. Selanjutnya perlu dilakukan setting port serial dari laptop yang dikoneksikan ke Arduino. Setelah koneksi dan komunikasi terjadi maka, software siap digunakan untuk di gunakan untuk 
menulis coding program yang nantinya program tersebut akan menjalakan perangkat arduino dan interface yang terhubung dengannya.

\section{Pelatihan}

Proses pelatihan dilakukan dengan terlebih dahulu memberikan pengetahuan dasar dan perkenalan dari mikrokontroller, sensor, dan komponen-komponen elektronika pendukung lainnya. Setelah itu dilanjutkan dengan bagian software. Siswa akan berlatih dari mulai merakit sampai dengan program tersebut running. Dengan demikian siswa diharapkan dapat mengerti bagaimana membuat / merakit hardware serta menjalankan software-nya.

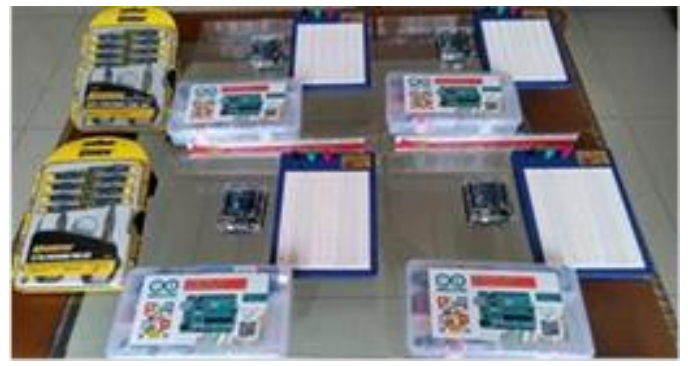

Gambar 1. Papan Arduiono Trainer

\section{HASIL DAN PEMBAHASAN}

Hasil dari penelitian Iptek Bagi Masyarakat ini adalah perangkat/modul Arduiono (Emulator) serta modul - modul pembelajaran atau pelatihan (Arduino Tutorial:2017), Berikut adalah modul-modul pelatihan yang dibuat, ada sebanyak 14 modul. Pada sub bab ini akan di perlihatkan foto /gambar rangkaian serta hasil dari modul yang dikerjakan.

\section{Modul Trainer Arduino Uno}

1. Gambar Skema dan Rangkaian Modul Lampu Kedip

Pada modul, ini lampu LED akan berkedip secara berkala. Dengan menghubungkan lampu LED serta resistor yang dihubungkan seri ke port data arduino, serta melakukan setting timer dengan nilai tertentu.

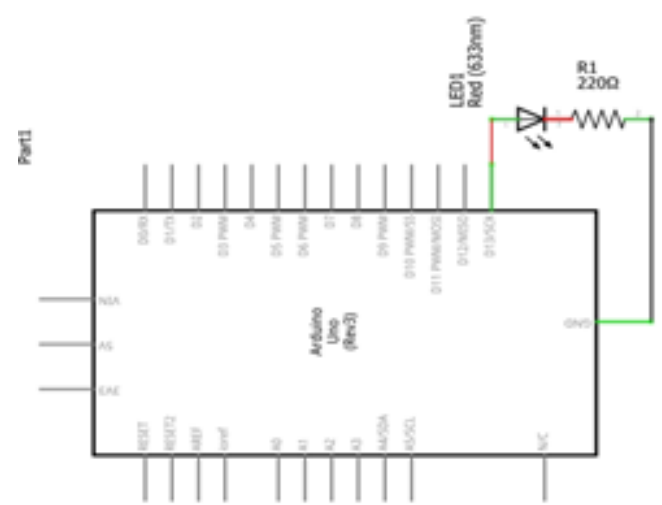




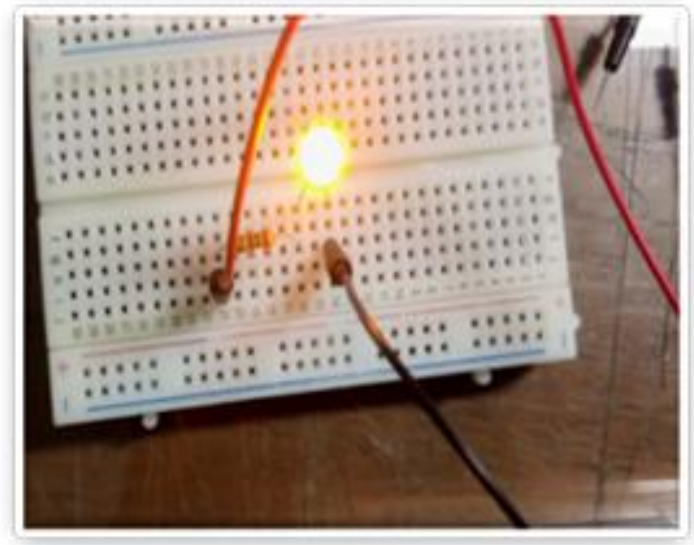

\section{Gambar 2. Rangkaian Modul Lampu Berkedip}

2. Gambar Skema dan Rangkaian Modul Generator Suara Alarm

Modul ini merupakan modul penghasil suara, yang selanjutnya dapat di implementasikan pada system alarm. Modul arduino dihubungkan ke buzzer. Buzzer akan berbunyi seperti alarm, dengan terlebih dahulu melakukan pemrograman/setting dari suara buzzer yang ingin dihasilkan.
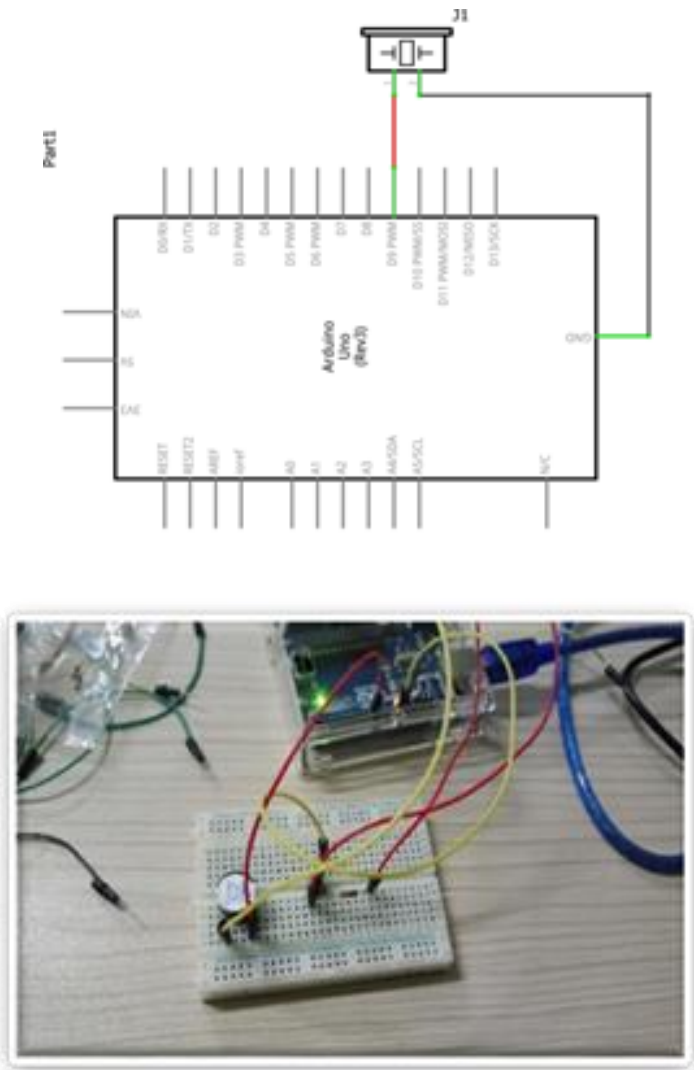

Gambar 3. Rangkaian Modul Generator Bunyi/Alarm

3. Gambar Skema dan Rangkaian Modul Traffic Light 
Modul ini merupakan dasar perancangan dari traffic light, 3 buah Lampu LED yang mewakili lampu traffic light (merah, kuning, hijau) dihubungkan dengan port arduiono. Selanjutnya dilakukan setting/program untuk masing-masing lampu berapa lama menyala dan mati.
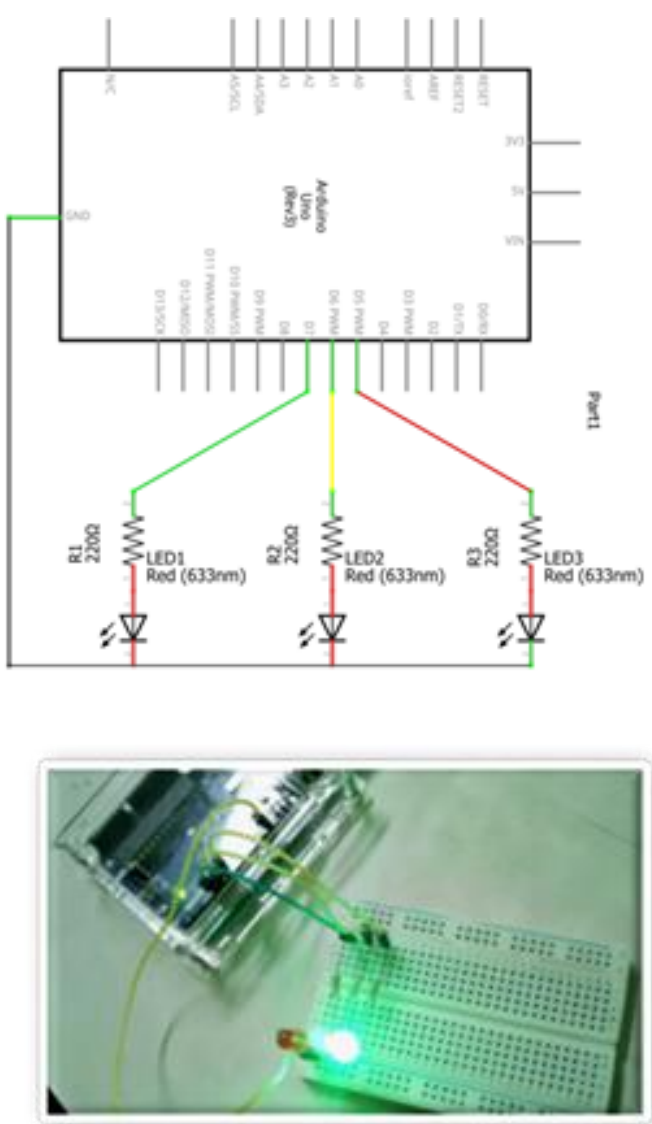

\section{Gambar 4. Rangkaian Modul Traffic Light}

4. Gambar Skema dan Rangkaian Modul Buzzer dengan Push Button

Modul ini memberikan pembelajaran hubungan switching dengan Arduino, dalama hal ini switch dihubungkan ke salah satu port Arduio dengan output buzzer. Dengan menekan tombol push button/switch, maka lagu /ringtone akan berbunyi sesuai setting nada/tone pada program. 

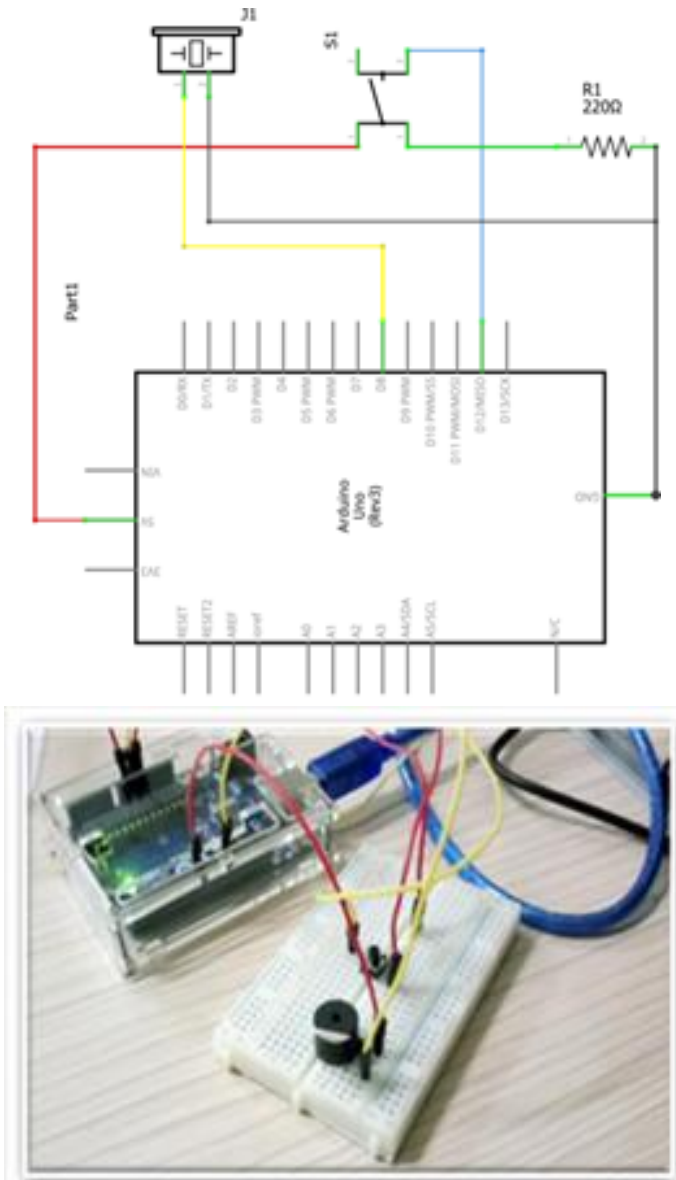

Gambar 5. Rangkaian Modul Buzzer

5. Gambar Skema dan Rangkaian Modul Seven Segment

Seven segmen menampilkan angka dan beberapa huruf, yang kita inginkan. Untuk itu perlu di koneksikan pin-pin dari seven segment ke beberapa port arduino, pembentukan huruf disesuaikan dengan program yang dibuat.

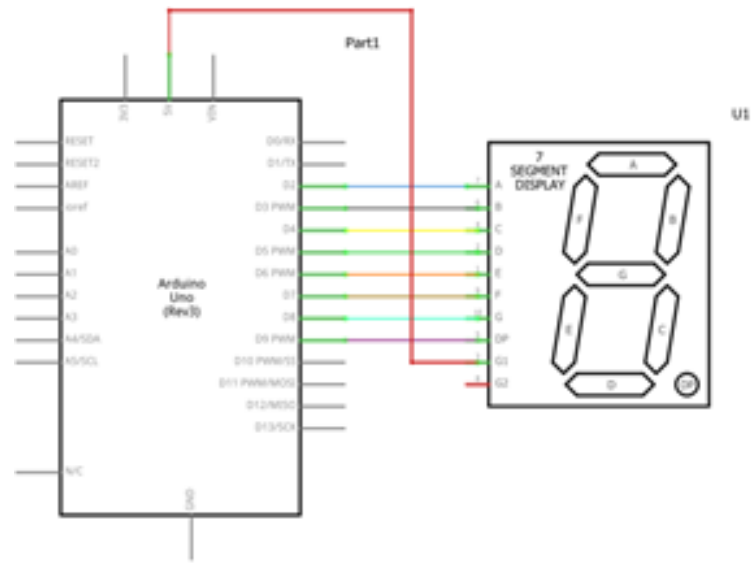




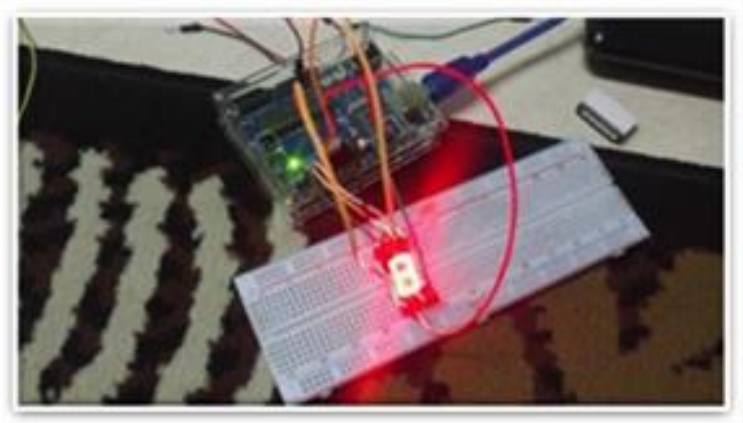

\section{Gambar 6. Rangkaian Modul Seven Segment}

6. Gambar Skema dan Rangkaian Modul LDR

Modul ini adalah gabungan dari fungsi switching dan monitoring, dimana akan terjadi input switching dari sensor LDR yang dipasang pada salah satu port Arduino, sebagai output adalah LCD yang akan menunjukan besarnya intensitas cahaya yang didapat dari sensor LDR.
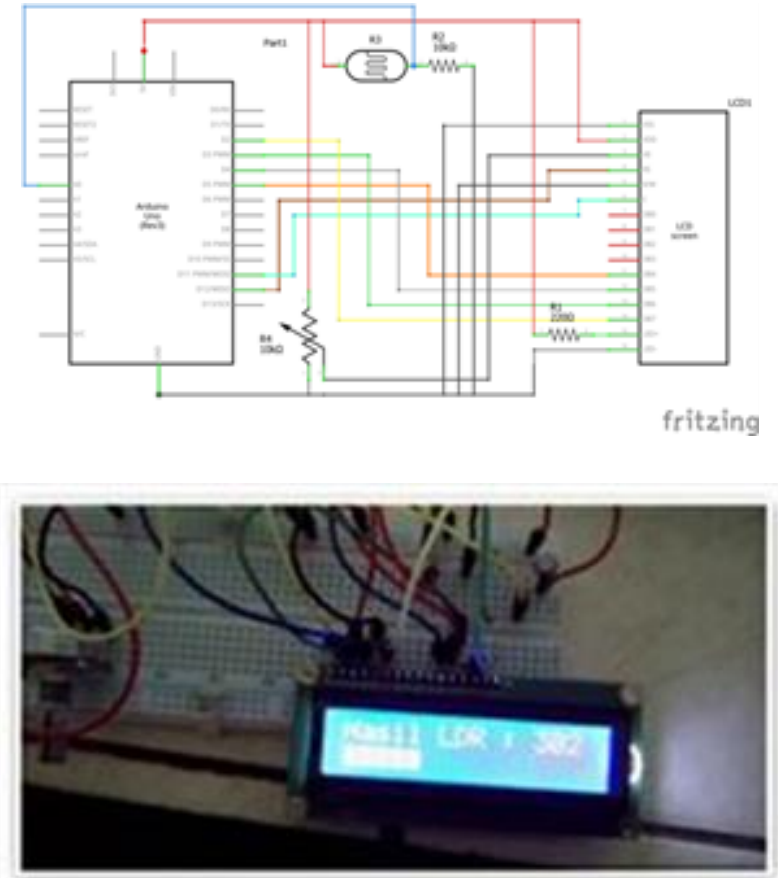

Gambar 7.Rangkaian Modul LDR

7. Rangkaian Modul Alarm dengan sensor LDR

Modul ini merupakan implementasi dari system control, dengan input sensor LDR yang disetting pada intensistas tertentu, dan pada output dipasang buzzer serta LED . Jika cahaya yang ditangkap oleh LDR (Light Dependent Resistor) sesuai dengan intensitasnya maka buzzer akan berbunyi, dan LED akan berkedip ketika LDR menerima intensitas cahaya sesuai dengan yang di sudah program sebelumnya. 


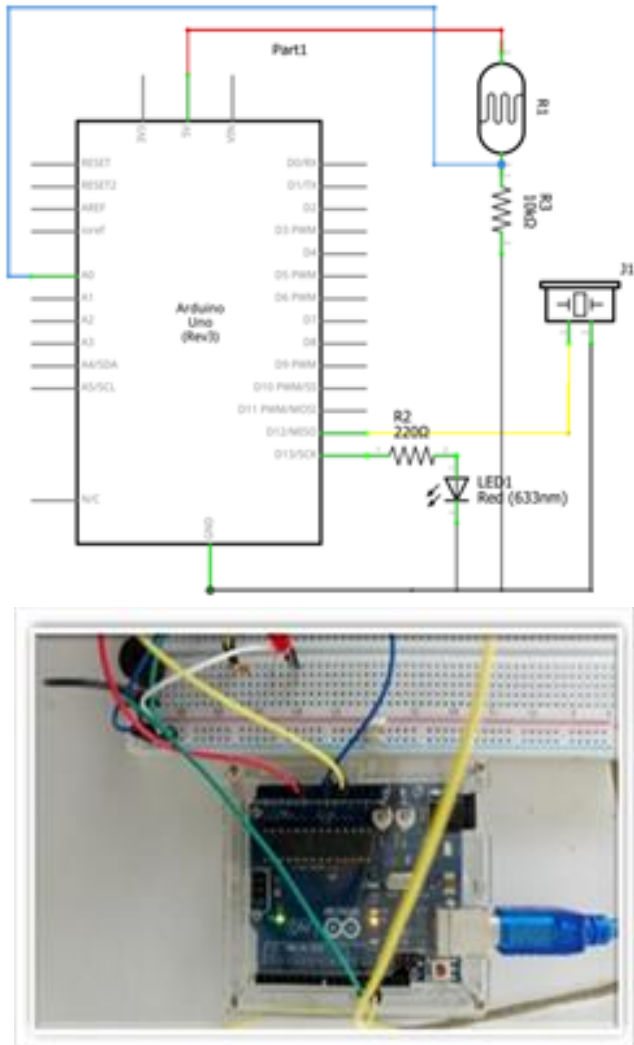

\section{Gambar 8.Rangkaian Modul Sensor LDR}

8. Gambar Skema dan Rangkaian Modul Potentiometer

Modul ini memberikan pelajaran bagaimana jika input analog berupa perubahan besar tahanan yang diwakilkan oleh potensiometer terhubung dengan port analog arduino. Dengan memutar potensiometer, maka input analog akan berubah-ubah dan dapat di amati pada display monitor (serial monitor).

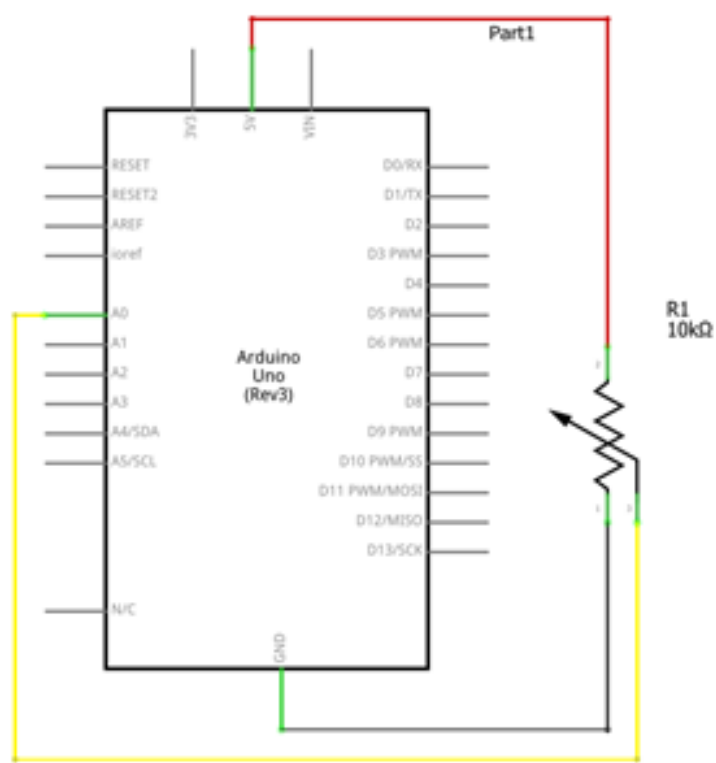




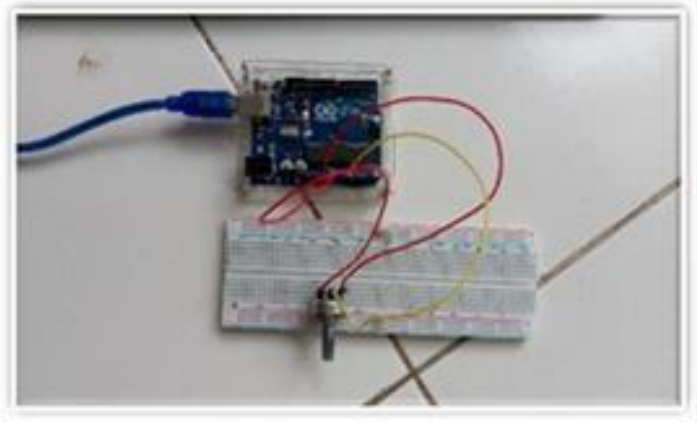

\section{Gambar 9.Rangkaian Modul Potensiometer}

9. Gambar Skema dan Rangkaian Modul Pengaturan Output dengan Pulse Width Modulation (PWM)

Salah satu keunggulan modul Arduino adalah tersedianya port output PWM, dengan mengkoneksikan LED ke port Arduino, dan menjalankan fungsi PWM pada program, maka lampu LED akan berubah intensitas cahayanya secara berkala, semakin terang, dan kemudian semakin redup.
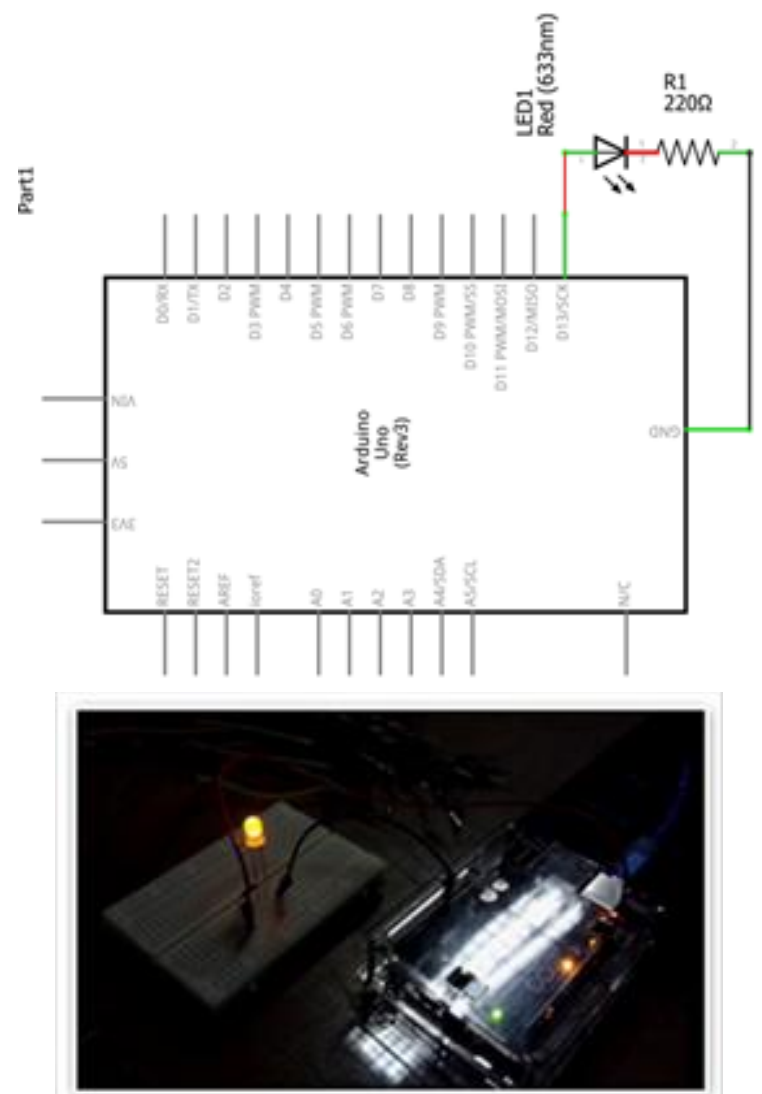

\section{Gambar 10.Rangkaian Modul Output PWM}

10. Gambar Skema dan Rangkaian Modul Terang LED dengan potensiometer 
Modul ini akan menunjukan bagaimana input analog (via Potentiometer) dapat digunakan pada Arduino, lampu LED dikoneksikan dengan salah satu port Arduiono, LED bisa di rubah intensitas cahayanya dengan menggunakan/merubah-rubah besaran tahanan potensiometer.
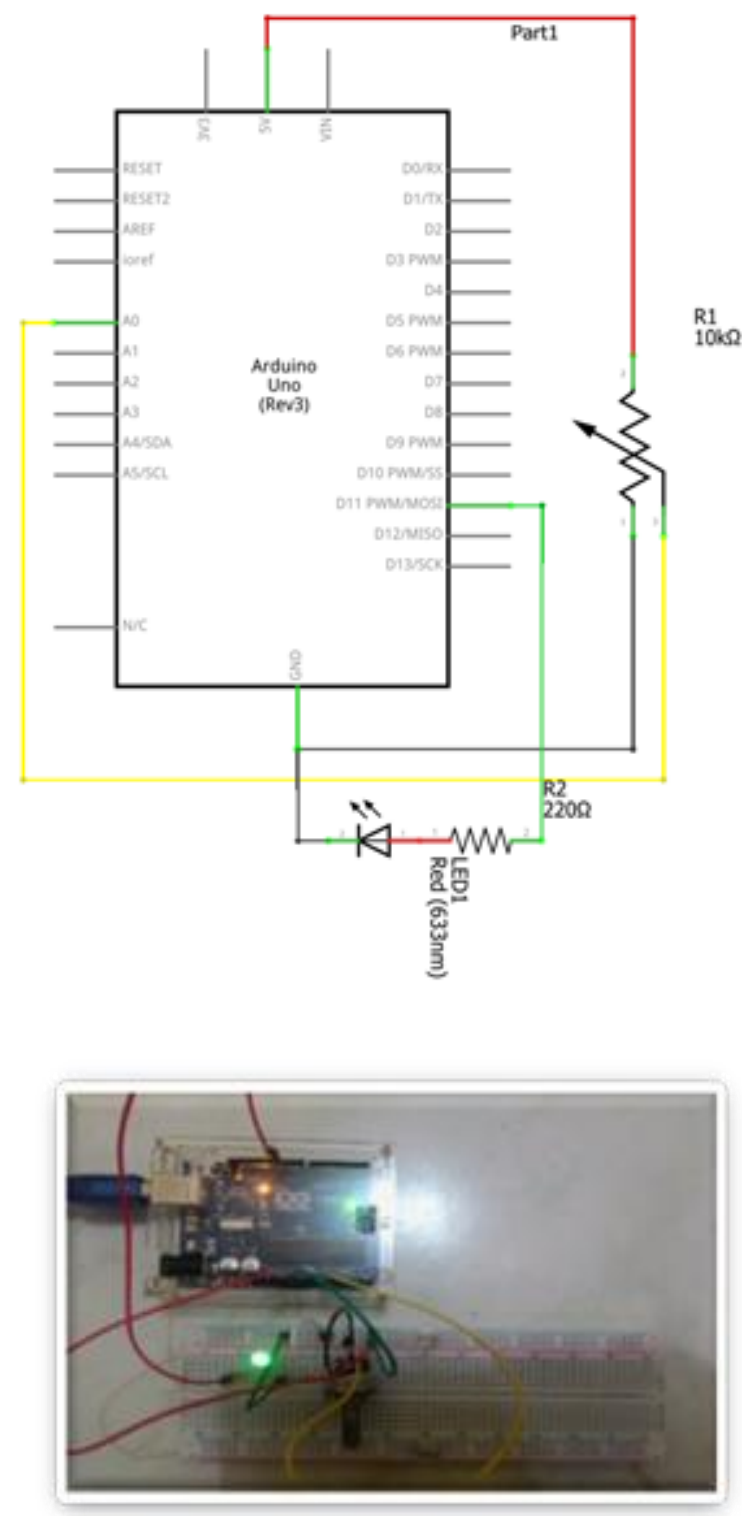

\section{Gambar 11.Rangkaian Modul LED dengan Potensiometer}

11. Rangkaian Modul Servo dengan Potensiometer

Pembelajaran pada modul ini adalah bahwa Arduino dengan input analog dapat mengontrol servo motor. Modul ini dapat digunakan dalam sistem kontrol mekanik dimana servo motor dapat dihubungkan lebih lanjut dengan sistem mekanik, misal tuas, yang terkoneksi dengan sistem mekanik portal. 

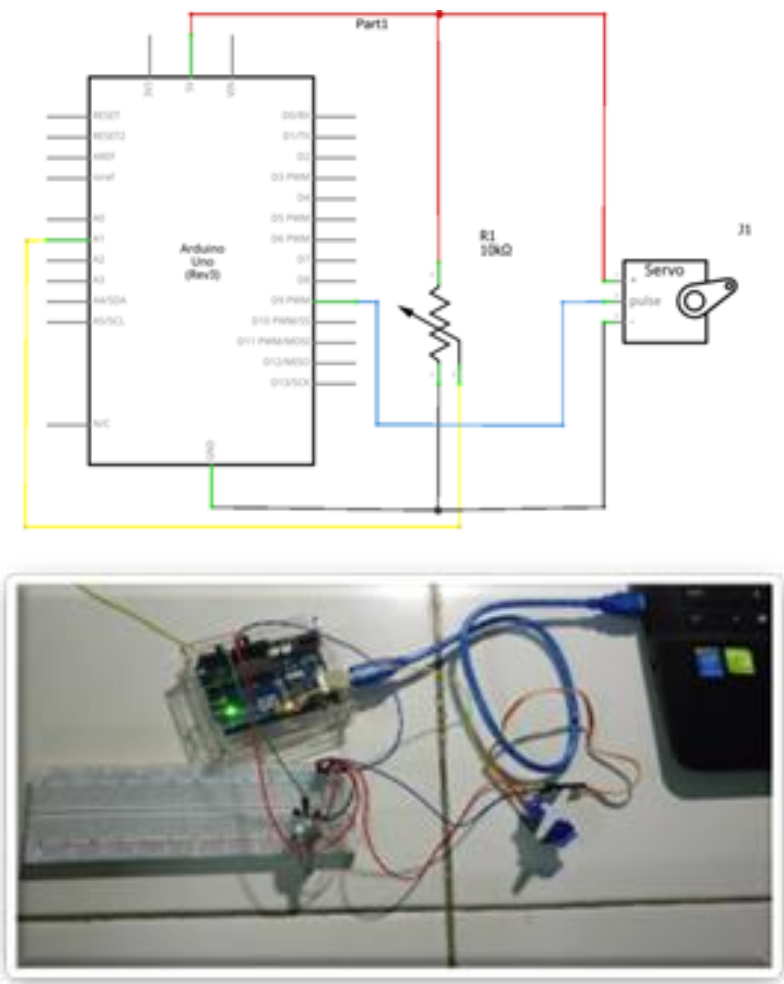

\section{Gambar 12.Rangkaian Modul Servo dengan Potensiometer}

12. Gambar Skema dan Rangkaian Modul Pengukur Jarak

Modul ini memberikan pengetahuan tentang penggunaan sensor, sensor jarak dan penggunakan LCD sebagai layar monitor. Percobaan yang dilakukan adalah mengukur jarak dalam ukuran centimeter dimana hasil pengukuran dapat di amati di LCD.
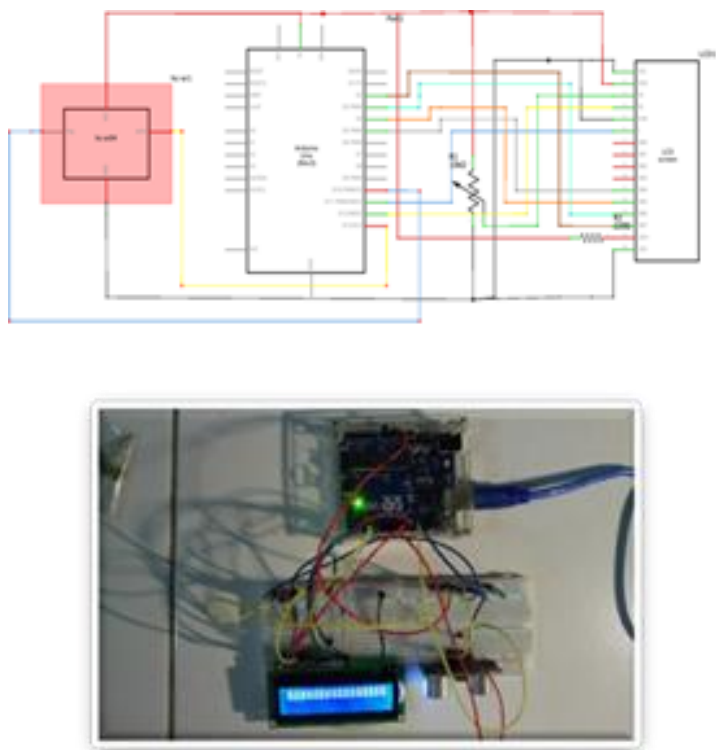

Gambar 13.Rangkaian Modul Servo dengan Potensiometer 
13. Gambar Skema dan Rangkaian Modul Running Text

Modul ini memanfaatkan penggunaan LCD untuk menuliskan informasi dan sekaligus menampilkan secara text berjalan. Isi tulisan/informasi serta arah text berjalan dapat di program sesuai keinginan pengguna.
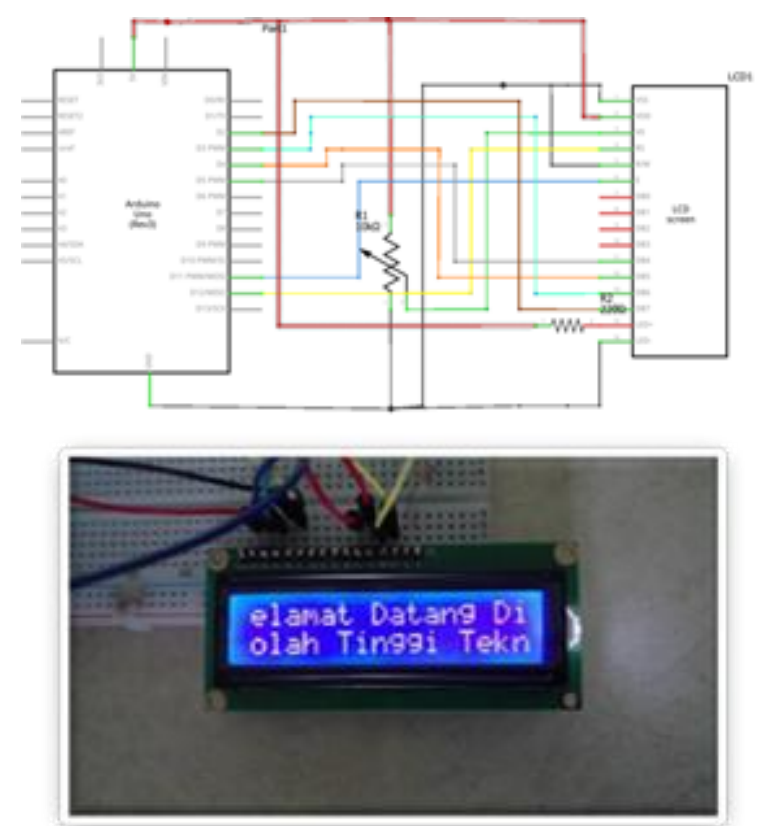

Gambar 14.Rangkaian Modul Running Text

14.Gambar Skema dan Rangkaian Modul Jam Digital

Modul ini adalah aplikasi Jam Digital, menunjukan jam dan waktu sholat. Modul Arduino dihubungkan dengan LCD disertai potensiometer untuk mengatur kecerahan layar LCD.

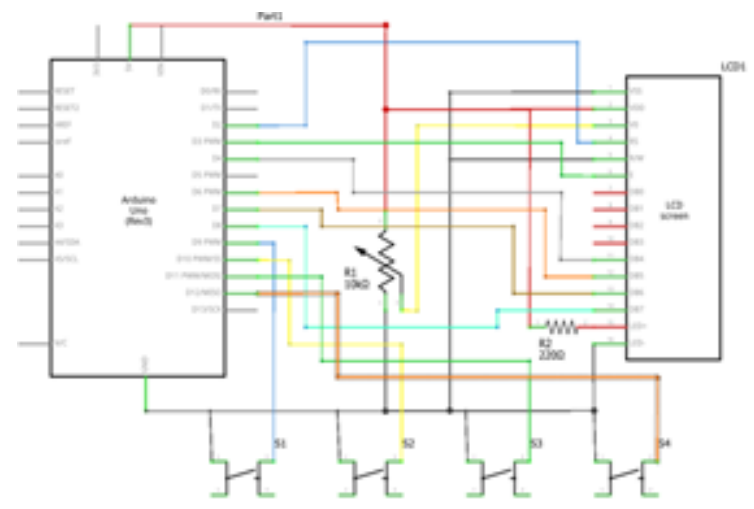




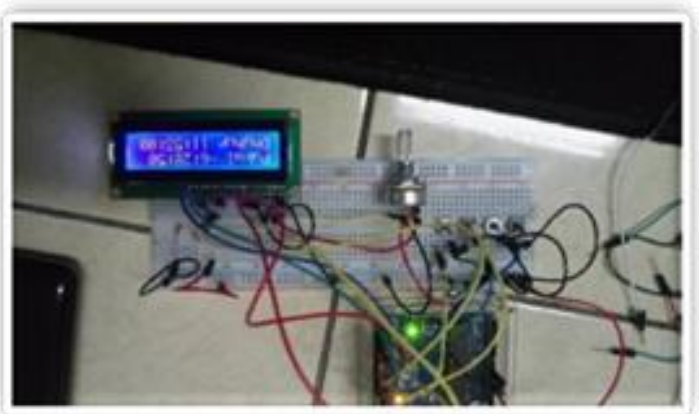

Gambar 15.Rangkaian Modul Jam Digital

\section{Modul Petunjuk Pratikum Arduino}

Setelah merangkai dan mencoba seluruh percobaan Arduino, Selanjutnya adalah pembuatan modul-modul petunjuk pratikum, ada 14 buah modul petunjuk pratikum dimana disetiap modul meliputi sub judul sebagai berikut:

$\begin{array}{ll}\text { - } & \text { Judul Modul } \\ \text { - } & \text { Tujuan } \\ \text { - } & \text { Dasar Teori } \\ \text { - } & \text { Kegiatan Praktikum } \\ \text { - } & \text { Peralatan } \\ \text { - } & \text { Rangkaian Arduino Uno } \\ \text { - } & \text { Sketch Arduino Uno }\end{array}$

Berikut adalah judul dari modul-modul pratikum/pelatihan yang dibuat:

E] 01. Modul Lampu Kedip.docx
E] 02 Modul Potentiometer.docx
E] 03 Modul Generator Suara Alarm.docx
E] 04 Modul Pengaturan Output dengan Pul...
E] 05 Modul Traffic Light.docx
E] 06 Modul Terang LED dengan Potensiom...
E] 07 Modul Buzzer dengan push button.do...
E] 09 Modul Servo dengan Potensiometer.d...
E] 10 Modul Running Text.docx
E] 11 Modul LDR.docx
E] 12 Modul_E3_Pengukur Jarak.docx
E] 13 Modul Alarm dengan sensor LDR.docx
E] 14 Modul Jam Digital.docx

Gambar 16. Modul-modul pelatihan

\section{Pelaksanaan Pelatihan Arduino Uno Trainer}


1. Untuk Pelaksanaan Praktek Kerja Lapangan Arduino Uno Trainer pada Siswa/i SMK INSAN MULIA Jatiasih Bekasi diadakan pada bulan Juli-Agustus 2017, yang bertempat di SMK INSAN MULIA Bekasi. Kegiatan Pelaksanaannya adalah:

\section{A. Pemberian Materi Arduino Uno Trainer.}

SMK

Sebelum melakukan pelatihan pada papan pelatihan arduino, maka siswa-siswi

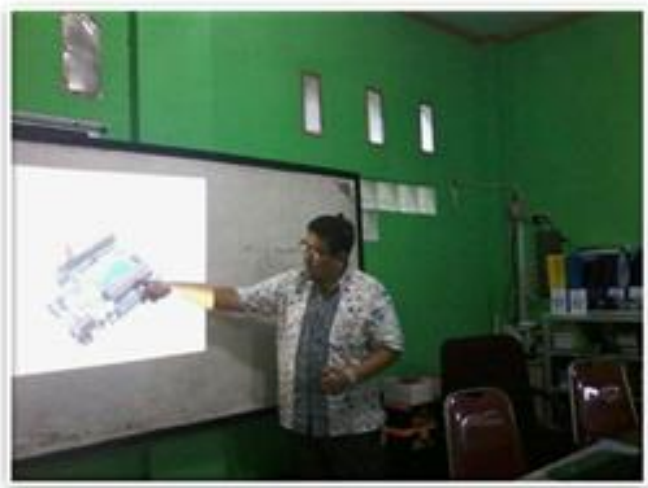

Gambar 17. Presentasi teori mikrokontroler

diberikan pengetahuan dasar mengenai mikrokontroller baik pengetahuan Hardware dan software. Pelaksanaannya lebih focus pada tanya jawab dan diskusi, serta memberikan beberapa contoh aplikasi mikrokontroller yang ada ditengah kehidupan kita. Pengetahuan teori ini diberikan secara bertahap, sambil diselingin praktik pada papan percobaan.

B. Kegiatan Pelaksanaan Arduino Uno Trainer Oleh Siswa/i SMK INSAN MULIA Bekasi.

Setelah pengetahuan teori diberikan dilanjutkan dengan melaksanakan pelatihan tersebut, dari memulai mengunduh software IDE Arduino,, mengistall-nya, kemudian menulis coding dan melakukan compile. Setelah itu mencoba membuat rangkaian sesuai petunjuk modul yang diberikan sampai dengan menjalankan program tersebut.

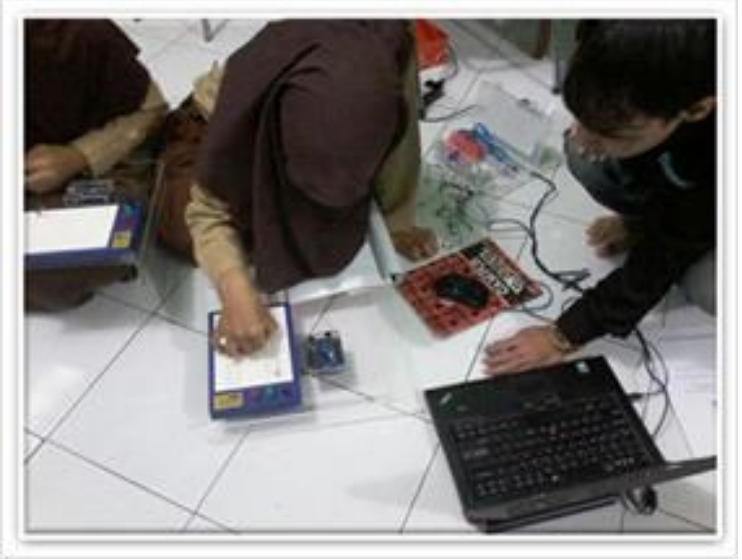




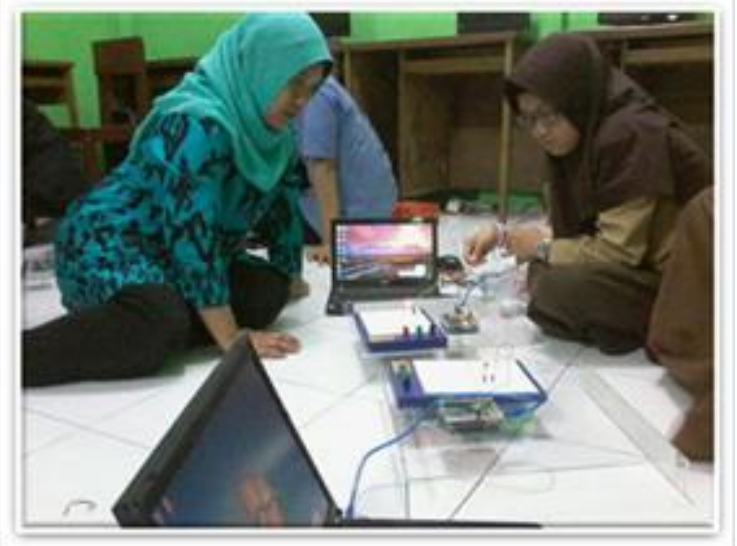

Gambar 18. Siswi sedang mengikuri modul pelatihan

C. Penyerahan Perangkat Arduino Uno TrIner kepada Pihak SMK INSAN MULIA Bekasi.

Di akhir pelatihan, perangkat Arduino di serahkan pada pihak SMK, ada 4 perangkat beserta tools, software, modul-modul pelatihan dan presentasi dari pelatihan tersebut. Dalam hal ini perangkat diserahkan pada koordinator guru elektronika, diharapkan dapat digunakan untuk membangun laboratorium mikrokontroler.
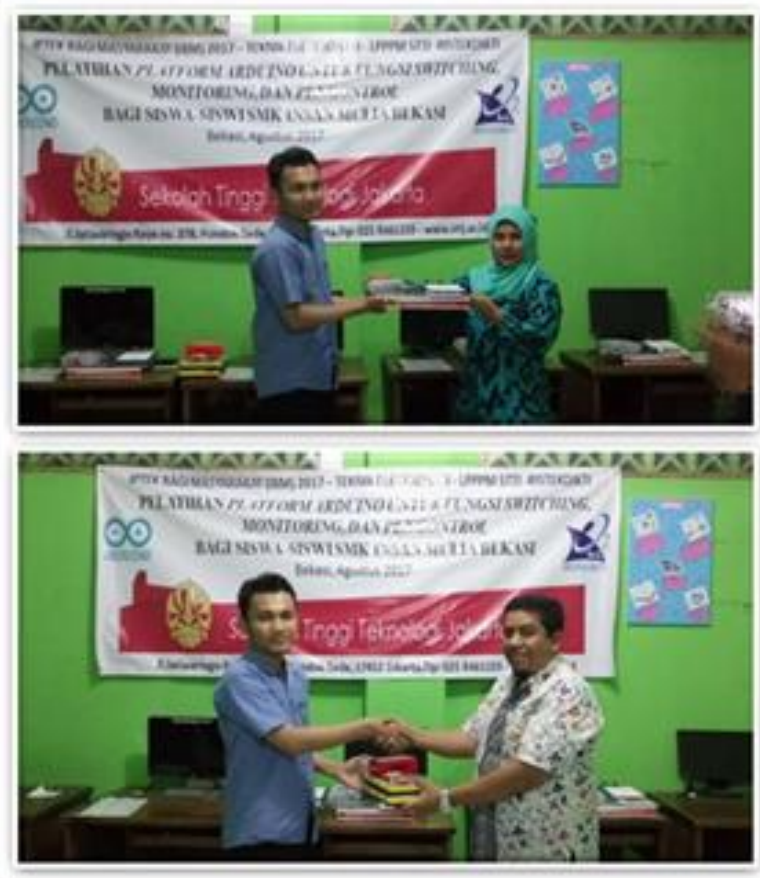

Gambar 19. Serah terima perangkat pelatihan serta tools untuk SMK

D. Foto Bersama Siswa-Siswi SMK INSAN MULIA Bekasi. 


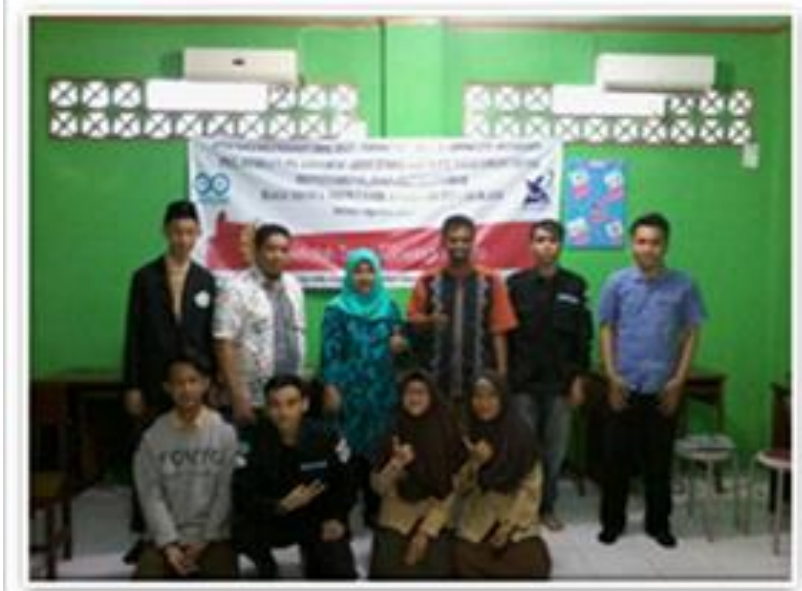

Gambar 20. Siswa-siswi, guru peserta pelatihan dan mahasiswa serta dosen pelaksan pelatihan

2. Untuk Pelaksanaan Iptek Bagi Masyarak (IbM) Arduino Trainer pada Siswa/i SMKN 1 BEKASI diadakan pada bulan Agustus -September 2017, yang bertempat di SMKN 1 Cikarang Kabupaten Bekasi dan kampus STTJ. Kegiatan Pelaksanaannya adalah:

\section{A, Pemberian Materi Arduino Uno}

Pelaksanaan pelatihan diawali dengan presentasi teori mikrokontroller baik secara hardware dan software. Pihak SMK mengikutsertakan 4 siswa (2 Siswa dan 2 Siswi) serta seorang guru koordinator. Diharapkan pengetahuan teori Arduino dapat ditularkan oleh guru dan siswa-siswi kepada teman-teman dan adik kelas mereka.

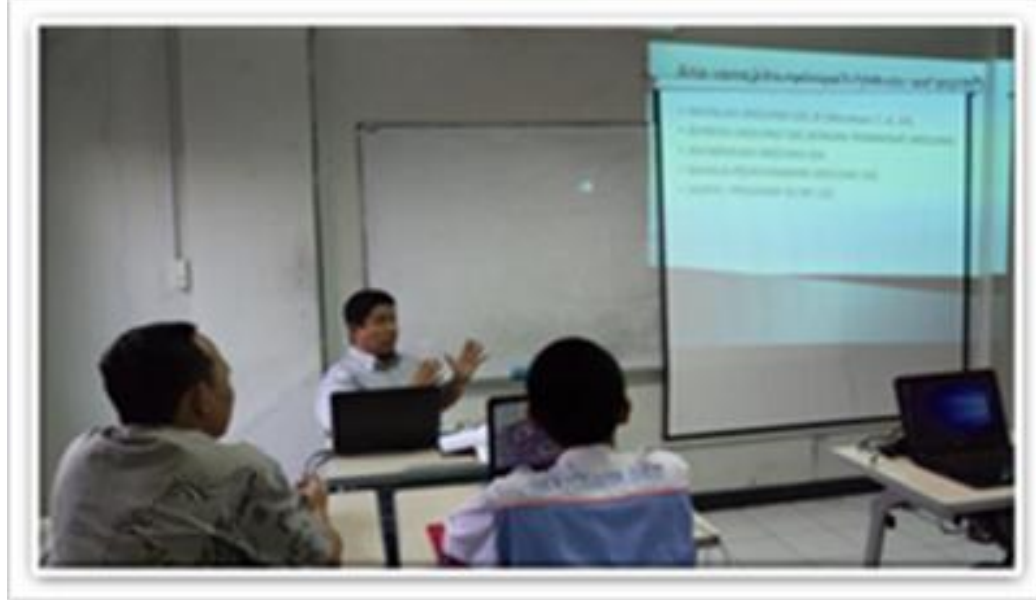




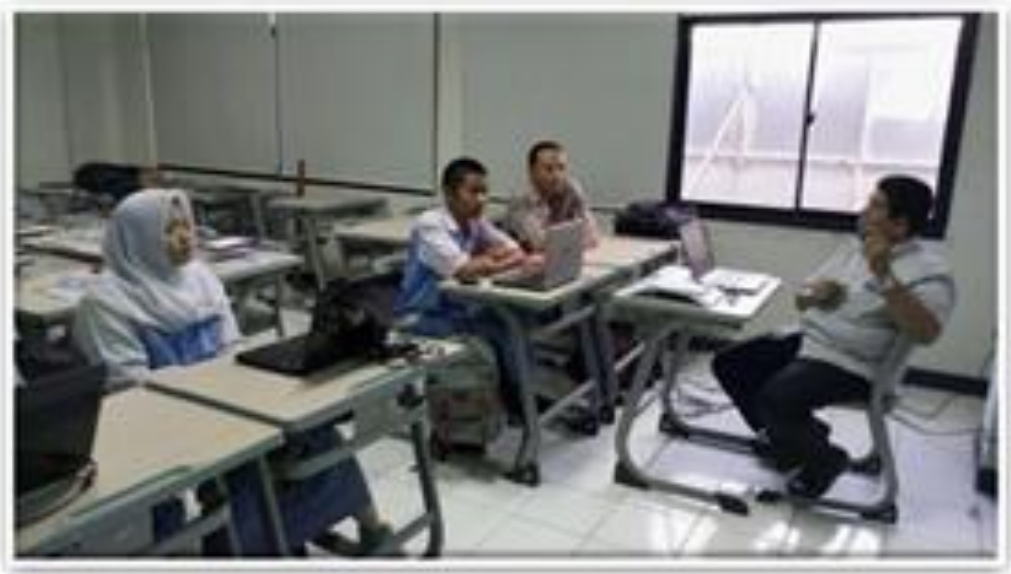

Gambar 21. Setiap pertemuan pelatihan diawali dengan diskusi teori mikrokontroller sebelum pelaksanaan pelatihan

B. Kegiatan Pelaksanaan Arduino Trainer di SMKN 1 Cikarang Kabupaten BEKASI.

Setelah mendapatkan teori dari Arduiono, di lanjutkan dengan praktik langsung di depan komputer, dimulai dengan instalasi software arduino IDE (Integration Development Environment) dilanjutkan dengan merangkai komponen dari setiap modul yang diberikan.

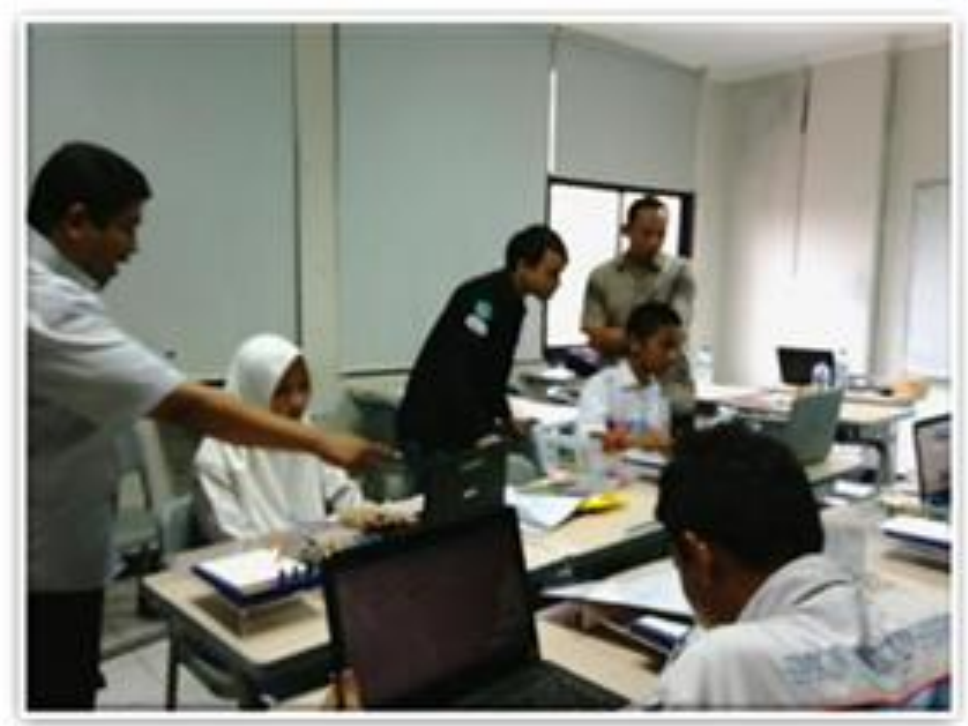

Gambar 22. Siswa-siswi SMK sedang mengikuti proses pelatihan dengan asistensi dari pelaksana penelitian Iptek Bagi Masyarakat.

C. Penyerahan Perangkat Arduino Trainier Kepada Pihak SMKN 1 Cikarang BEKASI.

Di akhir pelatihan, perangkat di serahkan kepada pihak SMK. Perangkat yang diserahkan adalah 4 unit papan arduino, tools, perangkat lunak, modul pelatihan dan presentasi pelatihan. 


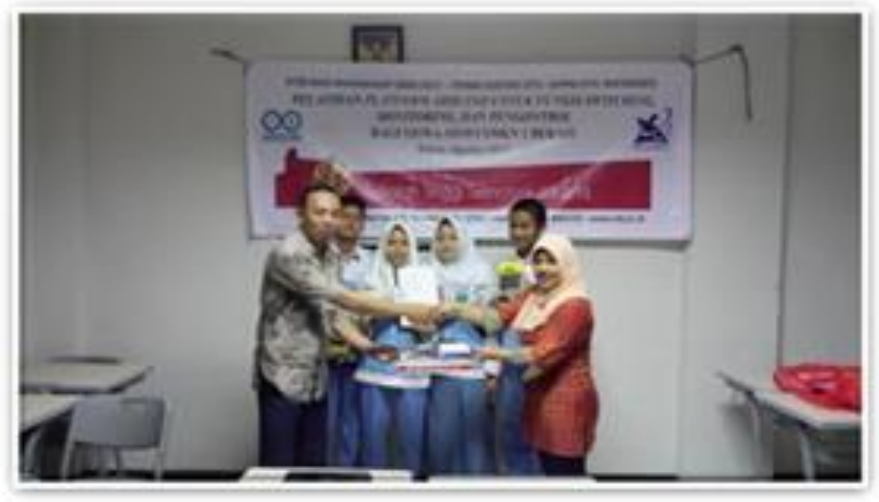

Gambar 23. Serah terima perangkat pelatihan

D. Foto Bersama Siswa/i SMKN 1 Cikarang BEKASI.

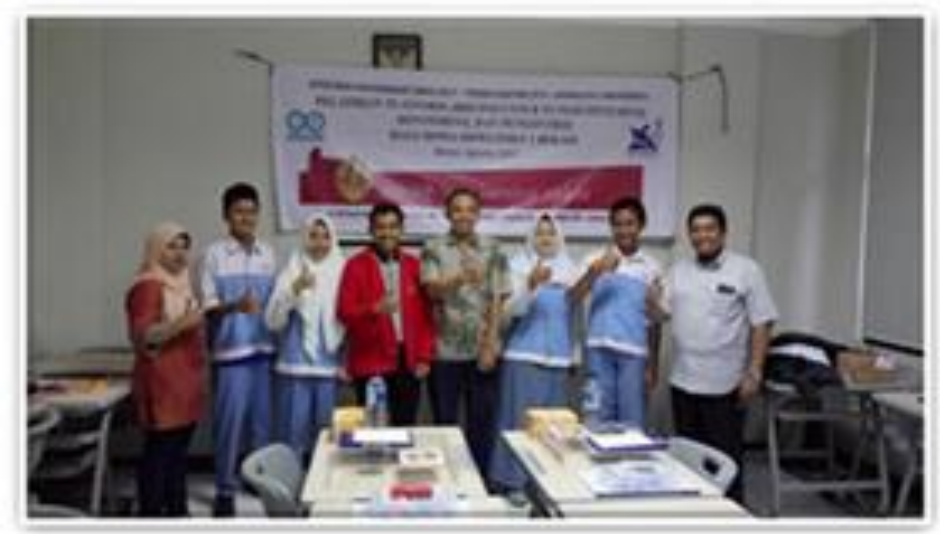

Gambar 24. Foto bersama di hari akhir pelatihan

Dari kegiatan pelatihan Arduino dalam Iptek Bagi Masyarakat ini, siswa-siswi SMK antusias dan merasakan manfaat karena mereka dapat mempraktikan langsung antara teori dan implementasi. Selama ini mereka tidak pernah menerima pengetahuan mengenai mikrokontoler terlebih mempraktekannya. Bagi pihak penyelenggra SMK dirasakan manfaat yang berarti karena mereka dapat langsung mengadakan laboratorium mikrokontroller dan sekaligus menjalankan pratikumnya. Beberpa analisa dari modulmodul yang dibuat, diharapkan dapat berkelanjutan dengan terus menambah modulmodul baru yang dapat di koneksikan di papan pratikum yang dibuat. Penambahan beberapa sensor seperti sensor temperature, sensor kelembaban, sensor detektor asap dan sensor-sensor lainnya akan memberikan nilai tambah tersendiri dari segi pratikum Arduino. Disamping itu diharapkan dapat juga ditambahkan modul-modul komunikasi dari Arduino, seperti Wifi, GSM, Bluetooth, sehingga dari segi komunikasi/koneksi ke dunia luar missal ke server dapat juga dipraktikan. Lebih tepatnya koneksi ke IOT (Internet Of Things) server. 


\section{Kesimpulan}

\section{KESIMPULAN DAN SARAN}

Pelatihan Arduino bagi siswa-siswi SMK di Kabupaten dan Kota Bekasi akan sangat berguna sekaligus memberikan kemampuan tambahan bagi mereka ketika memasuki dunia kerja di Industri elektronika dan kontol otomasi lainnya.

\section{Saran}

Kedepannya, diperlukan suatu pelatihan yang lebih mendalam untuk meningkatkan peran aktif siswa-siswi SMK dalam ikut mengatasi masalah-masalah yang muncul dalam dunia Industri dalam negeri khususnya. Pelatihan yang dapat diselenggarakan misalnya pelatihan koneksi ke sensor-sensor dan koneksi ke IOT server, interfacing dengan perangkat-perangkat di Industri khususnya yang berhubungan dengan Internet of Things (IOT) sehingga akan semakin menigkatkan keterampilan siswa-siswi SMK untuk dapat bersaing dalam menghadapi pasar lokal maupun global.

\section{DAFTAR PUSTAKA}

W.Durfee (2011), Arduino Microcontroller Guide, University of Minnesota.

Sudjana, N., \& Rivai, A. (1990). Me 20 smbelajaran. Bandung: CV Sinar Baru Bandung.

Purwanto, Ngalim. (1990). Psikologi Pendidikan. Bandung : Remaja Rosdakarya

Arduino Tutorials, diakses dari www.arduino.cc pada bulan Mei 2017. 